\title{
Formulation of Creative Tourism Products at The Area of Pendawa Beach Natural Tourism Village Kutuh Badung Bali
}

\author{
$1^{\text {st }}$ I Dewa Gede Ari Pemayun \\ Tourism Department \\ State Polytechnic of Bali \\ Badung, Indonesia \\ aripemayun@yahoo.com
}

\author{
$2^{\text {nd }}$ Luh Linna Sagitarini \\ Tourism Department \\ State Polytechnic of Bali \\ Badung, Indonesia
}

\author{
$3^{\text {rd }}$ A. Agung Putu Swabawa \\ Tourism Department \\ State Polytechnic of Bali \\ Badung, Indonesia
}

\begin{abstract}
This research was conducted in the Pandawa beach tourism area of Kutuh village, sub-district of South Kuta, Badung. The purpose of this reseach is to formulate tourism products that are in accordance with the potential that exists on Pendawa beach that can be categorized as creative tourism products and determine the management model of coastal tourism areas. Data collection was carried out using observation, interviews, focus grop discussion methods. The analytical tool used to analyze data is a qualitative analysis technique in the form of descriptive analysis and synthesis analysis. Based on the results of the analysis shows that creative tourism products that can be formulated based on the potential that exists on the Pandawa coast and based on the criteria of creative tourism products that are viewed from three dimensions, namely: Educational tours, Paragliding, Coral Reef Transplantation, Padma Bhuana tower, Maritime Museum, Cultivation Tourism and Seaweed Culinary. Pandawa coastal area management model, can be seen from two aspects, namely: 1) Functional management that is applied to pandawa beach tourism object is to use three (3) functions, namely: a) Strategy function, management of pandawa beach attractions setting goals and make operational plans. b) The function of internal components, management of Pandawa beach tourism organizing, staffing, directing, and operational supervision, c) Functions of external constituents, management of Pandawa beach tourism cooperating with third parties namely private and regional government. 2) From the systemic model, the management of the Pandawa beach tourism area that follows the management process comprehensively, the steps are as follows: a) Identify the tourism facilities offered on the Pandawa coast, b) The effective management structure, c) Determine the people who right, d) Making policies and rules, e) Doing coordination vertically and horizontally, and f) Making accountability reports.
\end{abstract}

Keywords: Formulation, creative tourism products, management models, functional, Systemic.

\section{INTRODUCTION}

According to the Law of Tourism No. 10 Year 2009 it is stated that marine tourism is an effort to conduct tourism and water sport, also infrastructure and suprastructure and other services which is managed commercially in the sea, beach, river, lake, and dam. Indonesia with its 17,504 islands and $95,181 \mathrm{~km}$ coastlines, beautiful beaches and highest sea biodiversity in the world means that Indonesia has the biggest potencies of marine tourism in the world [1]. Water has restorative qualities, passive observation of the maritime environment in itself has been described as a fundamental tourism activity [2]. The unique character of coastal environment gives to various types of tourism development. While tourism is a component of integrated approaches towards coastal and marine management, the natural environment and tourism are inextricably linked [3]. The development of marine attraction must be supported by developing villages-tourism to create some businesses in the society [4]. Development of marine tourism needs the right system and management and accurate target [5].

In fact where tourism has been a major issue in coastal areas and despite differences in locale and levels of economic development, there are strikingly similar evidences of environmental changes, mostly negative [6]. The utilization and development of marine tourism potential, must still ensure the environmental sustainability and cultural wisdom of local communities, with the aim [7]: to keep the ecological process going; protect biodiversity, and ensure the sustainability and utilization of species and their ecosystems. The development should also guarantee the environment conservation and the local genueus and culture in order to keep the ecological process; to protect biodiversity and to guarantee the preservation of the species and its ecosystem [8]. In the last decade Turkey has become a popular cruise tourism destination in Mediterranean basin and share in global cruise tourism industry.

Pandawa Beach is one of the tourist areas in Kutuh Village, approximately $3 \mathrm{~km}$ from the Nusa Dua Tourism area and Uluwatu Temple. This beach is located hidden behind a row of rock hills that are only overgrown with bushes, but the Badung Regency Government is aware of the tourism potential of the Pandawa beach. Starting in 2002, the access road was made to Pandawa Beach and data collection so that it was easy for vehicles to pass and could attract visitors. In December 2012 Pandawa Beach was officially opened, beginning with the Pendawa Beach festival. The potential in the form of: beach views with clean white sand, as well as calm waves, free of 
pollution and traders so that tourists can do maritime tourism activities with free. Many food stalls appear that sell fried rice, fried noodles, grilled sea fish and some types of western food. Food stalls provide sun loungers along with umbrellas that can be rented. With the development carried out by the Regency Government, Kutuh Village and Pendawa Beach Management Agency, yield results that can be seen from the increasing number of tourist visits. Where the level of tourist arrivals both foreign and domestic tourists from February 2013 to January 2014 fluctuated considerably in April, July, September and October experienced a decline, but overall increased by $26.59 \%$ for domestic tourists and $34.37 \%$ for foreign tourists. For twelve months from February 2013 to January 2014, the average monthly visit rate was 32,760 people for domestic tourists and 4,603 people for foreign tourists.

Pendawa Beach has a strategic location, when connected with the 4A concept, namely the distance and travel time to the destination are measured from the "accesable" airport from Ngurah Rai Tuban airport and hotels in southern Badung. Tourist attraction "attractions", Pendawa beach has the potential for marine tourism and paragliding attractions, the existence of tourism support facilities "amenities, which are currently being revamped as well as the existence of a" ancillary "tourism institution, the Pendawa beach management agency. Building tourism in Pandawa Beach means agreeing also to build tourist attractions "attractions" especially manmade tourist attractions, while for natural attraction and culture only arrangement and packaging is needed. Because the distance and travel time to "accesable" destinations close to Ngurah Rai Airport will eventually encourage the government to build a viable highway for tourist transportation to Pandawa Beach, which is currently working on the road to Pandawa Beach has begun, while tourism supporting facilities "amenities "Like hotels, inns, restaurants have also been prepared.

With the number of tourists visiting Pandawa Beach, the Joint Decree of the Kutuh Village and Kutuh Traditional Bendesa Village Number 01 of 2013 concerning the Improvement of the Establishment of the Kutuh Beach Area Planning Team (PKPK) which regulates the arrangement of the Kutuh Beach area which includes Pandawa Beach, Timbis Beach and Gunung Payung Beach. Specifically, the establishment of the Kutuh Beach Area Management Team establishes rights, obligations and authorities which include: 1) Obligations that consist of: a) carrying out data collection and mapping of the potential in the coastal area of Kutuh, b) making a master plan and detailed plan, c ) arranging work programs, grouping activity activities and carrying out physical activities in accordance with the needs of the field referring to Rp. Village-Village 2010-2015, d) arranging, supervising and fostering activities caused by the community or groups in the Kutuh Beach area in accordance with the limits of authority, e) carry out the management of income sources related to existing activities, as long as the special management body has not been established, f) recruit the required officers in accordance with the existing financial needs and conditions, g) report on the implementation of duties to the repair and customary law of Kutuh custom every month, 2) Rights which consist of: a) can manage operational funds those involving structuring costs, technical operational costs and other operational costs, which are derived from the results of the Kutuh coastal area management or other sources of income provided by the Kutuh Indigenous Village and Village government and third party assistance in accordance with the provisions provided by Kutuh Customary Village and Bendesa, b) the operational funds referred to in letter a above in their allotment can be further regulated by PKPK Team, 3) authority consisting of: a) to improve the management of the PKPK Team to cooperate with the village institutions or other parties by first coordinating with the Kutuh Defense Agency and Kutuh Adat Bendesa, b) seek other sources of income to support the structuring costs and operational costs of the PKPK Team.

As a new tourism destination, the Kutuh Beach Area Management Team together with the Dinas Desa government, Kutuh Traditional Village together with the Badung Level II Regional Government have begun to arrange the Pendawa beach with the hope that it will become an attractive attraction and even become a new paradise on the Island of the Gods. However, in order for its arrangement and development to be in line with market desires, its development is directed, in line with the meaning of Sapta Pesona which has been determined by the Decree of the Minister of Tourism, Post and Telecommunications Number: KM.5 / UM.209 / MPPT-89 which can create a sense of security. Order, Cleanliness, Coolness, Beauty, Friendliness, and Memories that are expected to become excellent and sustainable tourism objects. For this reason, we need to exemplify the potential, find input to tourism actors, academics and tourists to compile a blueprint for the development of creative tourism products. on Pendawa Beach. Pandawa beach tourism area has a form of: the scenery of the cliff is amazing, the sea water is still clean, the existence of coral reefs is still natural, while the weaknesses are: poor environmental management and inadequate public infrastructure.

Based on the background above and the results of the first year research, and so that the development of the natural area of Pandawa Beach is progressing, the main issues in this year's research are:

1. What creative tourism products can be formulated according to the potential on Pandawa beach?

2. How is the management model of Pandawa beach tourism area relevant to operational needs and development of Pandawa Beach area?

While the objectives to be achieved in this research are:

1. To formulate creative tourism products that can be formulated according to the potential that exists on the Pendawa coast and the development of tourist tastes.

2. To develop a management model for Pendawa beach tourism area that is relevant to the operational needs and development of Pandawa Beach area

\section{RESEARCH METHODS}

The approach used is a sampling approach, which takes several respondents as a sample of the existing population. In 
sampling, judgment sampling method is used, which is taking respondents as a sample intentionally for a specific purpose so that the respondent members who will be selected can represent the characteristics of the population where the respondent was taken. The method used to collect data, there are 4 methods, namely: observation, interview, documentation, and focus group discussion (FGD). The analytical techniques used are: 1) Quantitative analysis techniques, 2) Qualitative analysis techniques, in the form of: a) descriptive analysis, b) synthesis analysis, designing a management model of tourism areas by considering the potential, consistency and feasibility of the combined Pandawa beach tourism area with ideas that appear in the FGD.

\section{RESULTS AND DISCUSSION}

\section{A. Location of Pandawa Beach Bali}

Pandawa Beach Bali is the latest popular tourist spot located in the southern tip of the island of Bali, Pandawa beach is located in Kutuh Village, South Kuta district, Badung Regency. The distance from Ngurah Rai airport is $18 \mathrm{~km}$, approximately one hour depending on congestion on the trip. The interesting thing about the location of Pandawa Beach is behind the cliff, so this beach is called a secret beach, or a hidden beach. Many people really rate the Pandawa beach in Bali as a hidden paradise, so they are tempted to take an excursion to the Pandawa beach in Bali.

Before entering the Pandawa Beach area, we will be presented with views of limestone cliffs towering on the left and right of the road and beautiful beach views in front of them waiting. Pandawa Beach is located on the southernmost tip of the island of Bali where in this area the beaches are famous as beaches with clean and soft yellowish white sand, clear sea water and at low tide, this view on Pandawa Beach will look more beautiful than when plug it in

The cliffs located around the Pandawa Beach are carved by 5 statues of Pandavas and Dewi Kunti, which is why the beach was finally called Pandawa Beach. These statues are carved on the left side of the road, from the statue of Dewi Kunti, followed by 5 Pandavas including the Dharma Wangsa statue (another name Yudistira), Bima statue, Arjuna statue, Nakula statue and Sahadewa statue which is the main character of the Mahabarata story. Each of the statues has a height of 5 meters with a width of 2.5 meters with the image as below

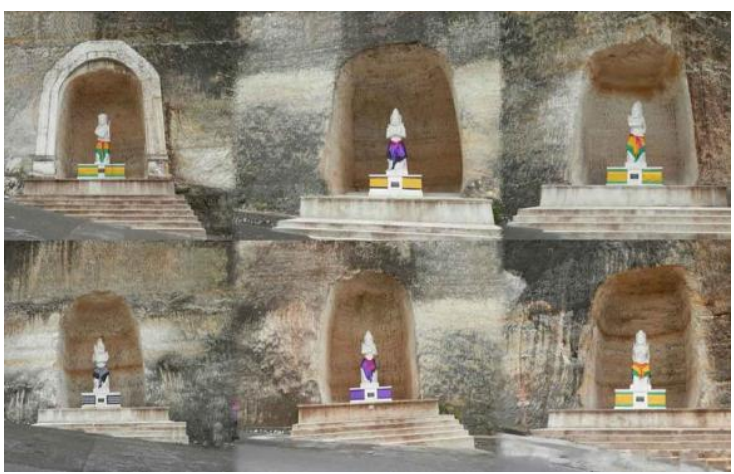

Fig. 1 Statue of Dewi Kunti and Five Pandavas on the Cliffs of Pandawa Beach in Bali

Sources: www.kompasiana.com

The existence of these statues was taken from a fragment of the Mahabarata story when the five masters were locked up in the cave of Gala-gala. The five Pandawa survived after they made a tunnel that led to a wilderness. In this forest, the Pandawa family founded the Amertha kingdom. This story is what inspired the community around Pandawa beach. Pandawa Beach has a length of 2 kilometers which is bordered by high limestone cliffs, so that the view from the top of the cliff and from the bottom of the cliff will look very charming

\section{B. Potential and Attractiveness of Pandawa Beach}

Pandawa Beach has various potentials that can be developed into tourist objects and attractions as well as being a medium for tourist attractions, including: 1) The towering limestone cliffs that are on the edge of Pandawa beach are very attractive, so this potential can be a natural tourist attraction. 2) White sandy beaches stretching $2 \mathrm{~km}$ in the enchanting Pandawa beach area, so that there are potential to develop several attractions, in the form of: sailling and tourism business in the form of: long chair rental, beach umbrella and traditional massage. 3) Seaweed, which is produced is very potential to be developed into various snacks and drinks that can be packed into souvenirs for tourists, or can be enjoyed directly at the time of visit. Seaweed cultivation can be used as a marine tourism agro attraction that can be enjoyed by tourists, ranging from planting, maintaining, harvesting and processing seaweed. 4) The clear blue sea is very potential to develop several tourism products, in the form of: canoe rentals, fishing boat rentals, and surfing which are marine tourism attractions. 5) Coral reef park (Coral garden) which is still a virgin, very strategic to be developed into diving and snorkeling tourism objects and attractions. The pictures of all these potentials are as below. 


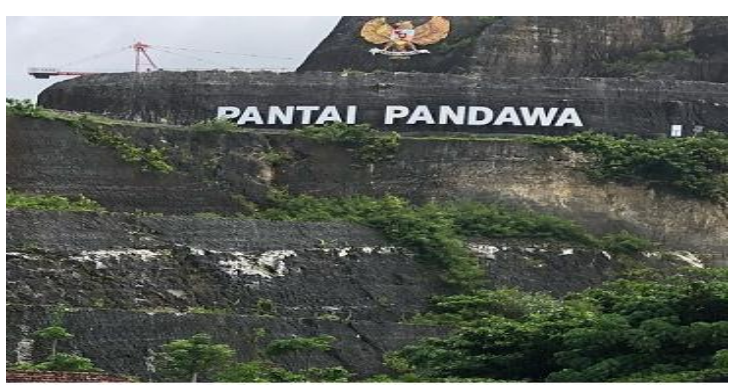

Limestone Cliffs

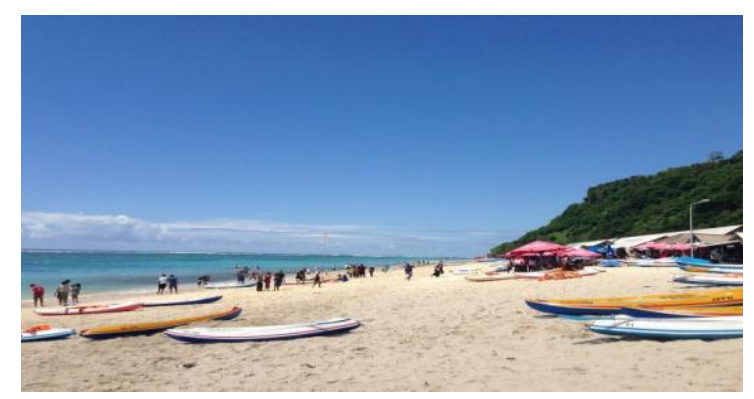

Sea and coast of Pandawa

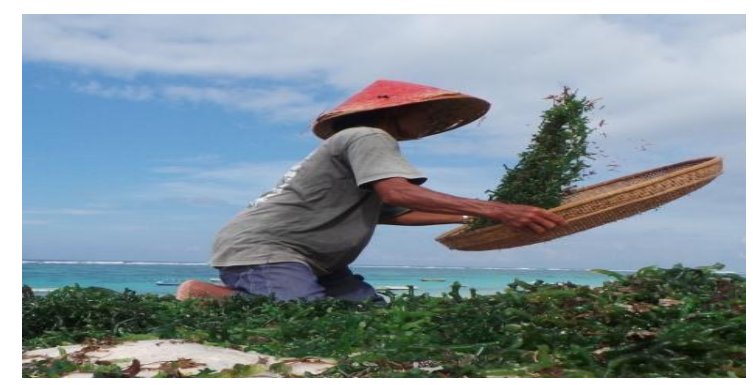

Weeding seaweed

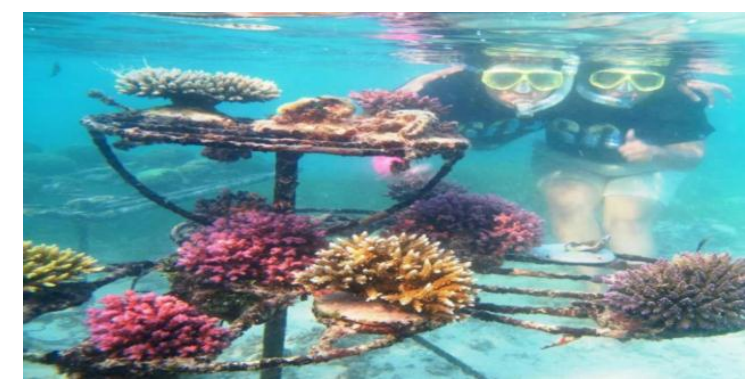

Coral reefs

Fig. 2 The Natural Potential of the Pandawa Coast

\section{Sources: www.kompasiana.com}

Socio-cultural potential which is the life of the Kutuh village community in the form of various types of regional arts and customs. The people still preserve traditional dances and dance performances in the form of Ramayana Ballet which are routinely performed during ceremonies at the three Kahyangan temples in Kutuh village. This dance is also often staged at the Pandawa beach stage along with the Kecak dance and Barong dance. There are also customs in the form of traditional ceremonies and traditions in the form of cremation ceremonies that have a special attraction that can be witnessed by tourists and a system of mutual cooperation that is still sustainable. There are also cultural objects in the form of temples with Balinese stil buildings with ornaments and there are statues of Dewi Kunti and Panca Pandawa on the cliffs along the road to Pandawa beach. On Pandawa beach there is also a coastal area that is purified by local residents. There are six areas purified in this area, namely cupid stone, melasti ceremony place, dalem segara temple, drinking water source wells of the villagers, sawan wela, and sawan sambang.

The potential of human resources in the village of Kutuh, where the elderly are initially fishermen and seaweed farmers, now most of them change their profession as entrepreneurs of tourism facilities. Their efforts include rental canoes, loungers, fishing boats, traditional footwear business, selling souvenirs, and culinary ventures (food and drinks). While the younger generation is still mostly studying in the field of tourism studies, so that the potential for effective development of Pandawa beach in the future is becoming a popular tourist attraction.

\section{Creative Tourism Product Formulation}

By looking at the potential that exists on the Pandawa coast, and based on a critical analysis of creative tourism products, innovative, creativity-based community, and supported by the ability to use technology involving tourists, of all new tourism products operated in 2018, in the process of development and arrangement, and tourism products that will be developed, then those that include creative tourism products, namely:

1. Educational tourism, in the form of tourism products that emphasize the learning process about culture, environment and institutional management models

2. Paragliding (paragliding), in the form of tourist facilities that do not yet exist in other tourist areas in Bali, especially in marine tourism objects. Likewise the production process and consumption happened simultaneously, there was an edification before the operation of this tourism product.

3. Coral Reef Transplantation, involving tourists and tourists as well as being able to travel to enjoy the underwater world, this coral transplantation process is educated and the process is very unique.

4. Padma Bhuana Tower, is a community art creativity, which is an innovative and unique Balinese architectural work. So that this tower tourism product will be an icon of Pandawa beach tourism.

5. The Maritime Museum, is an effective learning media about the history and culture of coastal communities, in addition to presenting the creativity of the maritime community.

6. Cultivation Tourism and Seaweed Culinary 
This tourism product is loaded with educational processes and can involve tourists in the production process, especially the resulting culinary tourism products are very innovative

\section{Management Model of Pandawa Beach Tourism Area}

Management of the Pandawa beach tourism area is basically a management of the environment and tourism facilities in the Pandawa beach area. Where the management model that needs to be applied is a model that fits the operational needs and development of the Pandawa beach area.

Functionally the management applied to Pandawa beach tourism is to use three (3) functions, namely:

1. The function of the strategy, management of Pandawa beach tourism is to establish goals and make operational plans to achieve the objectives so that the management carried out on Pandawa beach tourism can be carried out properly.

2. The function of internal components, management of Pandawa beach tourism objects is organizing, staffing, directing, and monitoring and evaluating.

3. The function of external constituents, management of Pandawa beach tourism establishes cooperation with third parties, namely private and regional government.

But in the process or from the systemic model, the management of the coastal natural tourism area Pandawa that follows

a comprehensive management process whose steps are as follows:

1. Identifying tourism facilities offered at Pandawa beach

In the management of the Pandawa beach area, it is necessary to identify tourism facilities existing and environmental conditions in the Pandawa beach tourism area. There are three main components, namely the environment, infrastructure and tourism facilities in the natural tourism area of Pandawa beach that need to be managed, namely:

a. Environmental arrangement, in which activities carried out in the arrangement of the environment in the Pandawa beach area are: Conducting hygiene activities in the coastal area, parking, and the environment around the area of tourism facilities. Doing evasion in the form of planting shady trees in the parking area, on the beach, and around the area of tourism facilities. Planting grass in the framework of garden arrangement in the Pandawa Beacon Sign area.

With regard to environmental management, where the problems faced are complaints of tourists about the coolness of the environment, especially the lack of shade trees and the problem of coconut shell waste

b. Management of tourism infrastructure, related to the provision of basic tourism facilities in the form of: highways leading to Pandawa beach, parking lots, electricity, clean water, toilets, telecommunications, health services, money changers, security posts, information service centers, Gazebo, and so on. The purpose of managing this facility is to avoid over and under capacity that will disturb tourists' comfort. The problems faced are: The number of toilets and their cleanliness is inadequate, the parking area is still lacking, especially in the high season, the lack of money changer business, the communication signal is not good.

c. Management of Tourism Facilities, where tourism facilities in the Pandawa beach area, belong to the Kutuh Indigenous village which is communal in nature and there are personal properties that are personal. For personal tourism products, the management is carried out by each entrepreneur. For the management of tourism products that are communal, the management is carried out by forming a business unit of all tourism products offered in the natural tourist area of Pandawa beach. The business units that are formed related to the management of tourism products in the Pandawa beach area are: the attraction unit and the Pandawa beach tourism project, the Paragliding tourism attraction unit, the art and cultural tourist attraction unit, the tourist transportation service unit, the educational tour service unit, and health service units. All of the above business units are under the auspices of Pandawa beach management, so that their operations are under the coordination and supervision of Pandawa beach management.

\section{Effective management structure.}

The organizational structure that is prepared describes a management model is real, because the organizational structure is a system that describes a collection of components that are interconnected and interact with each other in an environment to achieve goals. In accordance with the activities carried out, both for operational and development needs, the organizational structure of Pandawa beach management as shown below 


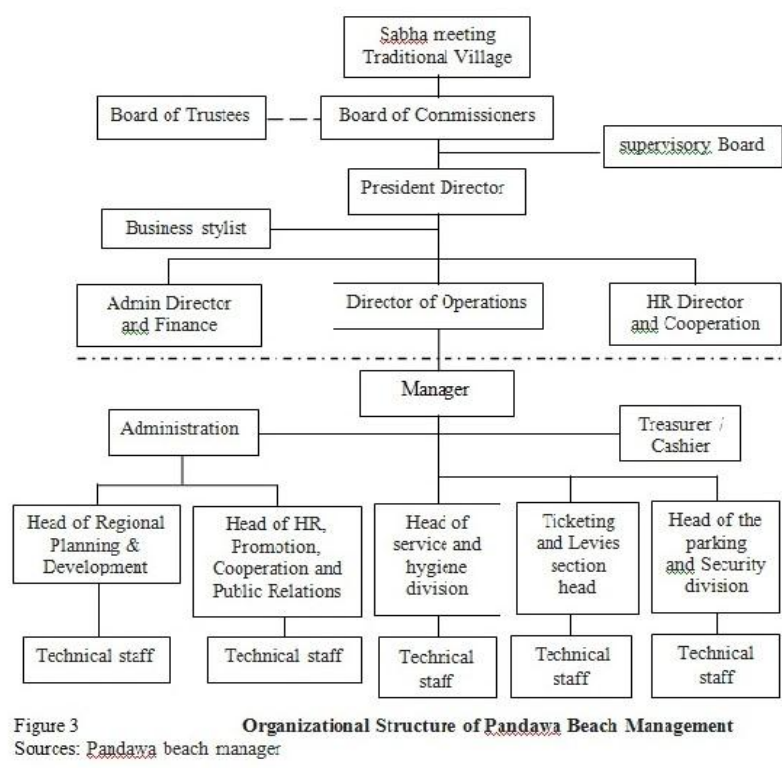

\section{Determine the right people}

In the coastal area management of Padawa, the number of personnel is 8 managerial personnel and 45 operational personnel. The manager of the Pandawa beach management is I Wayan Kasim, the head of Administration is I Wayan Letra, and Treasurer is Ni Putu Sinta Noviyanti. All personnel involved in the current management structure, education is still a high school and lower school. But with the rapid development of the Pandawa beach area and the demands of quality services by tourists getting better, and more empowering local people, the managers set the following requirements: indigenous people of Kutuh village, S1 education for managerial workforce, high school education and equal staffing, junior high school education down and without education for cleaning staff.

With regard to human resources, there are several problems that occur which include: weak human resource capacity in the field of language and hospitality issues (hospitality), and work discipline issues.

\section{Making policies, rules and schedule of activities}

Regarding policies, rules, and activity schedules that are made by companies that provide and offer personal tourism products that have been determined by each company in accordance with the conditions of the entrepreneurs themselves and tourist demand. However, in the management of tourism products that are communal, there are several policies established by the managers of the Pandawa coast:

\section{a. Tariff policy}

Tariffs applied to foreign tourists differ from tariffs for domestic tourists, as well as between adults and children. In the Pandawa beach area many tourism products are offered at different rates, with the rates as in table below

\begin{tabular}{|c|c|c|c|c|c|}
\hline \multirow{2}{*}{ No. } & \multirow{2}{*}{$\begin{array}{l}\text { Tourism Products / } \\
\text { Activities }\end{array}$} & \multicolumn{3}{|c|}{ Amount of Rates (RP) / person } & \multirow{2}{*}{$\begin{array}{c}\text { Duration } \\
\text { (hourminute }\end{array}$} \\
\hline & & \begin{tabular}{|l} 
Foreigners \\
\end{tabular} & \begin{tabular}{|l|} 
Domestic \\
\end{tabular} & Infor- & \\
\hline 1 & Rates enter the area & \begin{tabular}{|l|}
15.000 \\
10.000 \\
\end{tabular} & \begin{tabular}{|l|}
8.000 \\
4.000 \\
\end{tabular} & $\begin{array}{l}\text { Adult } \\
\text { Child }\end{array}$ & 2 \\
\hline 2 & Cultural performance & \multicolumn{2}{|c|}{$\begin{array}{l}100.000 \\
10.000\end{array}$} & \begin{tabular}{|l|} 
Foreigners \\
Domestic
\end{tabular} & 1 \\
\hline 3 & \begin{tabular}{|l|} 
Canoe \\
\end{tabular} & \multicolumn{2}{|c|}{50.000} & - & 1 \\
\hline 4 & Umbrella \& long chair & \multicolumn{2}{|c|}{50.000} & - & 2 \\
\hline 5 & \begin{tabular}{|l|} 
Fun Game \\
\end{tabular} & \multicolumn{2}{|c|}{80.000} & - & 3 \\
\hline 6 & Seaweed education & \multicolumn{2}{|c|}{80.000} & - & 3 \\
\hline 7 & $\begin{array}{l}\text { Planting coral reefs } \\
\text { (packages) }\end{array}$ & \multicolumn{2}{|c|}{80.000} & - & 3 \\
\hline 8 & Snorkeling & \multicolumn{2}{|c|}{100.000} & - & 45 \\
\hline 9 & Photo prawedding & \multirow{2}{*}{\multicolumn{2}{|c|}{$\begin{array}{c}500.000 \\
1.000 .000\end{array}$}} & - & Free \\
\hline 10 & Shooting ads & & & $\cdot$ & Free \\
\hline 11 & Go to documentation & \multicolumn{2}{|c|}{50.000} & - & Free \\
\hline 12 & Go Drown shootin & \multicolumn{2}{|c|}{500.000} & - & Free \\
\hline
\end{tabular}

\section{b. Retribution Policy}

The levy policy applied by the Pandawa coastal area manager is in the form of fees: parking for motorbikes and cars, food stalls and souvenirs, umbrellas and long chairs, where the amount of levies collected is in table below

Table 2

Retribution Policy

\begin{tabular}{|c|c|c|c|}
\hline No. & Information & Basamya Retribusi $(\mathrm{Rp})$ & Waktu \\
\hline 1 & Shop stalls, souvenirs & $\begin{array}{l}400.000 \text { - stand milik desa Adat } \\
100.000 \text { - stand milik sendiri }\end{array}$ & Per-bulan \\
\hline 2 & Cleaning money & 25.000 & Per-bulan \\
\hline 3 & Electricity and water & Sesuai dengan pemakaian & Per-bulan \\
\hline 4 & $\begin{array}{l}\text { Business canoes, umbrellas } \\
\text { and long chairs }\end{array}$ & $5 \%$ dari hasil yang diperoleh & Per-bulan \\
\hline
\end{tabular}

Source: Pandawa beach manager

\section{c. Contribution policy}

The contribution policy applied in the management of the Pandawa coastal area is related to the magnitude of the acquisition or net profit obtained by the Pandawa coastal area manager. Contributions given are directed at various interests and objectives to be achieved, the magnitude of which is in table below

\section{Table $3 \quad$ Profit Contribution}

\begin{tabular}{|c|l|c|c|}
\hline No & \multicolumn{1}{|c|}{ Target } & Contribution (\%) & Time \\
\hline 1 & Unit development reserve & 40 & Year \\
\hline 2 & Special Reserves & 8 & Year \\
\hline 3 & Reserve Development objectives & 12 & Year \\
\hline 4 & Development of traditional villages & 23 & Year \\
\hline 5 & Production service & 7 & Year \\
\hline 6 & Coaching funds & 5 & Year \\
\hline 7 & Social Fund & 5 & Year \\
\hline
\end{tabular}

Source: Pandawa beach manager

\section{d. Other Policies}

In the management of Pandawa beach area, there is a business unit that is managed separately under the auspices of Pandawa beach management, so there is a policy that is established, in the form of: 
1) Management fee policy of $5 \%$ of the total ticket sales that must be given to the

2) Pandawa beach management every 6 months by the unit manager.

3) Commission policy of $50 \%$ of the published price given to guides or parties who bring tourists to use tourism facilities on the Pandawa beach.

4) The results of the levy are submitted to the Regional Treasury of the Badung Regency, and returned $75 \%$ to the manager of the Pandawa beach.

5) Operational policy. This policy regulates the scheduleof activities carried out in environmental management. Where Pandawa beach operations start at 8:00 a.m. - 1.00 p.m.

Regarding the rules that are applied in the management of Pandawa beach tourism areas are directed at two targets, namely:

\section{a. Visitors / tourists}

Related to the safety of tourists, both foreign and domestic the cleanliness of the Pandawa coast, there are several regulations set by the management of the Pandawa beach, which include:

1) Travelers are prohibited from throwing trash carelessly, throw it in the available trash can.

2) Tourist women who are in aid (coming months) are prohibited from bathing in the sea.

3) Travelers are prohibited from sitting in a holy place.

b. The community, entrepreneurs and personnel of Pandawa beach management

The regulation made is oriented to cleanliness and service, where the rules set in the form of:

1) Local people visiting Pandawa beach are prohibited from littering.

2) Employers must clean their business area three times a day

3) Entrepreneurs are prohibited from littering, if violating three times, their business license is reviewed.

4) Pandawa beach employees must provide the best service to tourists / visitors

\section{Coordinating}

Coordination is carried out in the management of the Pandawa coast through communication, both vertical and horizontal. Vertical communication from the manager to the treasurer, administration, and to all divisions and parts under it, especially in providing instructions. Meanwhile, the heads of departments and divisions gave instructions and briefings to staff. Horizontal communication occurs between the treasurer and administration, and between the sections / divisions that have the natural management structure of the Pandawa coast. Communication is carried out with the aim of consolidating and coordinating work.

\section{Make accountability reports.}

Accountability reports are made in daily, monthly and annual forms. Where accountability is made usually in the form of financial statements from the results of transactions that occur in the operation of the Pandawa coast. Daily reports are made by retribution staff, monthly reports are made by the treasurer, while annual reports are made by administration with the treasurer.

\section{E. $\quad$ Analysis of Pandawa Beach Area Management}

The management model that has been applied to Pandawa beach management, still there are problems faced, both problems related to environmental arrangement, as well as related to the management of tourism facilities and infrastructure. So for that, it is necessary to improve the model related to the system by restructuring. Based on the above problems, it is necessary to improve the structure (restructuring) of the organization, where the proposed restructuring is as shown below

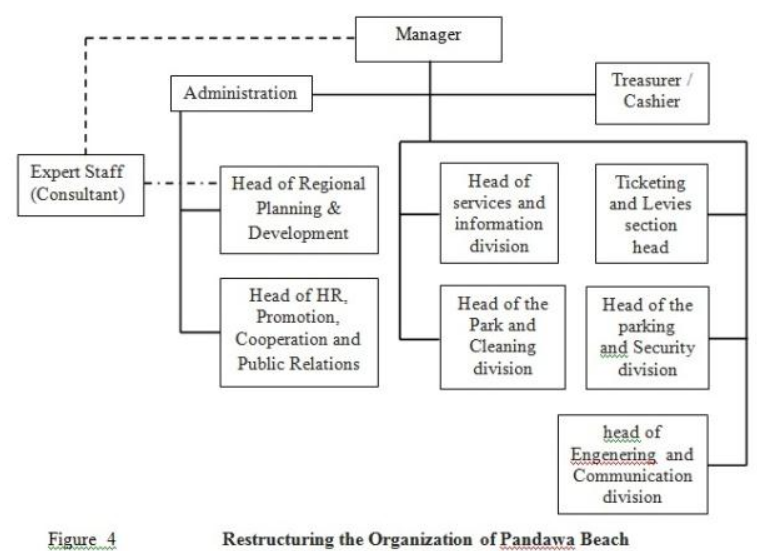

To be able to design creative tourism products and determine the feasibility of tourism products, it is necessary to have an expert as a consultant who provides consultation and makes a feasibility study of the creative product to the manager and head of planning and development. To overcome the problems that occur related to the arrangement of the environment and management of tourism facilities and infrastructure, it is necessary to develop a division of the service and hygiene division developed into 2 divisions, namely: service and information division and gardening and hygiene division. Given the rapid development of the natural tourist area of Pandawa beach, it is necessary to have an engineering and communication division. With the restructuring of the Pandawa Beach Organization like this, it is more fun for all activities and more effective. Besides, it is also necessary to involve academics to help provide various training in the form of training in the production of tourist products and language training and guiding in the framework of providing 
services to tourists who visit and use various facilities in the Pandawa beach area

\section{CONCLUSIONS AND SUGGESTIONS}

From the results of the above discussion, the following conclusions can be drawn:

1. Creative tourism products that can be formulated based on the potential on the Pandawa coast and based on the criteria of creative tourism products that are viewed from three dimensions, such as: Educational tours, Paragliding (paragliding), Coral Reef Transplantation, Tower Padma Bhuana, Maritime Museum, Budi Tourism Power and Culinary Seaweed

2. The management model of Pandawa coastal area management can be seen from two aspects, namely:

a) Functionally the management applied to Pandawa beach tourism is to use three (3) functions, namely:

1) The function of the strategy, setting the goals and priorities of the organization of the management of Pandawa beach tourism and making operational plans.

2) Function of internal components, organizing, staffing, directing and controlling.

3) The function of external constituents, to collaborate with third parties, namely the private sector and the Regional Government.

b)In process or from a systemic model, the steps are as follows:

1) Identifying tourism facilities offered on Pandawa beach.

2) Formulation of management structures effectively in accordance with operational needs and development of the Pandawa coastal area

3) Determine the people who will be placed in units within the Pandawa beach management structure, with the following conditions: Indigenous people of Kutuh village, S1 education for managerial workforce, high school education and equivalent for staff, junior secondary education and without education for cleaning staff
4) Making policies and rules in the management of the natural tourist area of Pandawa beach, where policies are in the form of: Tariff policies, retribution policies, contribution policies, other policies, operational policies. While the rules apply to tourists / visitors, entrepreneurs, and the community.

5) Coordinating vertically and horizontally

6) Making accountability reports, especially making financial reports, both daily, monthly and yearly.

3. Conducting structural improvements (restructuring) of Pandawa's coastal management organization, by adding components of experts as consultants, and developing the division of the service and hygiene division developed into 2 divisions, namely: service and information division and gardening and hygiene division. Besides involving academics to help provide various training and other forms of development.

Seeing the problems that occur in the management of the Pandawa coastal area, and the demands of tourists as well as the increasingly fierce competition between providers of tourism products in tourist destinations, it is advisable that beach managers always innovate to design creative tourism products based on community creativity. In formulating creative tourism products should involve professionals, in addition to the need to involve academics in the framework of developing effective tourism products

\section{REFERENCE}

[1] Gunn, Clare A., (2002). Tourism Planning : Basics, Concepts, Cases, Taylor and Francis Books, Inc, New York.

[2] Miller, M. and Ditton, R.D. (1986), Travel, Tourism and Marine Affairs, Coastal Zone Management Journal, 14(1/2)

[3] Peter Mason, 2003. Tuirism Impacts, Planning and Managenent, P Elsevier Butterworth-Heinemann Linancre House, Burlington

[4] Bakkara, Riana UWK dan Sunantri, Yudy. 2012. Analysis of Marine Tourism Potential through Approach CBT (Community Based Tourism). in the Main Tanjung of Batam City. Batam International University

[5] Siti N. 2001, Plan for the Physical Development of Marine Tourism Areas in the Indonesian Coastal Area. Bulettin Indonesian Parks and Landscapes. Planning, Design and Management, Volume 3, Number 2 , 2000. Gardening Architecture Studio Faculty of Agriculture IPB Bogor

[6] Johnston C., J. Liu and K. Din. 1991. Coastal and Marine Tourism. Annals of Tourism, vol. 18, $\mathrm{n}^{\circ}$ 3, p. $523-525$.

[7] Nurif, M. 2017, Mitigating risk of maritime regulatory changes : Oil tanker owners' perspective, International Conference

[8] Peter Mason, 2003. Tuirism Impacts, Planning and Managenent, P Elsevier Butterworth-Heinemann Linancre House, Burlington 